DOI: 10.2478/pcssr-2018-0014

\title{
Moderato: Master and disciple - A Case Study in the Olympic Landscape
}

Authors' contribution:

A) conception and design of the study

B) acquisition of data

C) analysis and interpretation of data

D) manuscript preparation

E) obtaining funding

\section{KEYWORDS}

\author{
Jerzy Kosiewicz \\ Josef Pilsudski University of Physical Education in Warsaw, Poland
}

ABSTRACT

The text characterizes the master-disciple relationship, which is interpreted in a historical context (of ancient Greece) and the contemporary one. In the first case it refers to the connection taking place between Socrates and his disciples (and especially between him and Plato). In the second case the author presents a study of one case of a supposed master-disciple relationship as a typical case study. He comes to a conclusion that the occurrence of such a relationship depends on two persons: a master and a disciple. When both of them agree that there was, there is and, maybe, there will be such a connection between them, it can be proclaimed with certainty that such a relationship existed or can start to exist. However, when any party of the supposed relationship is of an opinion that it has never existed, it is necessary to concede that (s)he is right, since it is not proper when one party maintains against the second party's will - or without his/her knowledge - that there was a master-disciple relationship between them.

master, disciple, case study, Olympic landscape

\section{Overture on the master and the grim reaper}

There exists a conception - approved not only in the scientific milieu - concerning a supremely distinguished person who is called a master and who is characterized by noteworthy achievements, e.g., in the field of medicine, art (music, ballet, acting, directing, painting, or sculpting), or the military, political, judicial, scientific, and philosophical fields. This refers to figures who have exerted a considerable influence on a generation, big or small social groups, or particular individuals. That relation is emphasized, among others, during jubilees of writing activities; before, after, or during funeral celebrations; and in incidental - but significant - recollections, sometimes of a posthumous character.

Nota bene, death should not be feared, at least in:

a) the ontological sense, since it does not exist as a being (unless hypostatically);

b) the Epicurean sense, because - briefly speaking - it does not concern us, since when it is we are no more and when we are it is not yet;

c) the Platonic and the Socratic sense (the sequence is not random), because an ostensible death (ostensible - taking into account intentions included in points $a$ and $b$ ) is simultaneously a transition to immortality: especially in master-disciple relations (disciples). Socrates' disciples - and especially Plato in his five arch-dialogues dedicated to the master - were those who provided him with philosophical immortality. It is significant that, as a matter of fact, the bulwark of Socrates' immortality - which is continuously seminal - is constituted by Plato's immortality (the immortality of his works). 
The concept of a master is closely connected with the concept of a disciple who, like Plato and others, refers to his - Socrates' - beneficial influence. Despite the fact that there are various axiocreative feedback loops between them, the opposite situation - when a master refers to a disciple - happens more seldom. Even more seldom is the situation when a master points out a disciple who does not know about that connection, and it is an extremely rare situation when the discussed disciple has never perceived that complex influence exerted on him by the master and still does not see it. In the case of Socrates, the influence exerted on a disciple had an unusual, complex, deepened, and distinctly original character. It included several significant components and subcomponents, namely:

a) teaching,

b) moral education,

c) philosophizing

- elenctics,

- maieutics,

- protreptics.

In ancient times, for example in the times of the sophists' activity, the disciple-master relationship (who were both people of the male sex) was connected with a bilateral aspiration for wisdom and knowledge. Until the times of Aristotle, those notions were synonymous (Pseudo-Platon 1973, p. 236; Domański 1996, pp. 5-6; Kosiewicz 2017b, pp. 98-99). The abovementioned relationship was significant in the social, cultural, and scientific sense, connected with knowledge about the world and the gods, about society, and about ethical norms of unqualified - that is, universal (like in Socrates' ethics) - and qualified relative (like in Protagoras' moral philosophy) character. Sophists were not only teachers - that is, providers of objectified intuitive knowledge about foundations of the world and the meaning of its existence - but also, like Socrates and Protagoras, practicing philosophers and educators of the young people who were attracted to them. This reinforced their authority and status among their disciples, who were thirsty for their wisdom and guidelines.

It is known that Socrates was a stone-cutter who did not live an affluent life. His unpretentiousness and modesty regarding the temptations of earthly life were impressive. He shied away from wealth and honors. Diogenes Laertius points out that Duris of Samos - a historian - "makes him out to have been a slave and to have been employed on stonework" (Diogenes Laertius, II, 5,19). He was characterized by dignity, firmness, and an uncompromising attitude regarding philosophical, moral, political, and judicial statements. That hemlock Athenian - unlike all other sophists - "was teaching gratuitously because selling wisdom was regarded by him to be equally despicable as selling love or friendship" (Krokiewicz 1995, p. 247). In spite of the fact that there were sons of rich aristocrats in his circle - and he could count on their financial support - he ate modest contribution meals with his disciples and became poor in his old age (Krokiewicz 1995, p. 249).

In contacting his disciples, Socrates applied the maieutic (obstetrical, extracting) method, which had been preceded by elenctics - that is, by the critical study of ethical knowledge and rejection of what seemed to be false wisdom, untrue explanations, understanding, and justifications of moral postulates and activity. The culmination of his endeavors, which simultaneously had an educational, teaching, and philosophical character, was protreptics, which he treated as a call for moral life, virtue, and getting rich on the infamous gilding of ethical ignorance (cf.: Krokiewicz 1995, pp. 251-254). He was looking for moral wisdom along with his disciples. He was looking for something that he knew to exist and whose existence was not perceived by them. They helped each other and together were striving to find non-empirical knowledge that could not be gained by the experiences of life. They made epistemological endeavors of an intuitive character. Thus, they discovered something that man had been given directly by the gods and that existed in rational human nature. From this, they extracted and presented revealed knowledge - that is, wisdom; virtue of divine provenance; something to cause man in the ethical, axiological, and epistemological sense to live on the border between two worlds: the phenomenal one and the ideal one.

Comparing the sophistic-Socratic-Platonic context of the master-disciple relationship and the encompassed educational, teaching, and philosophical values (including elenctics, maieutics, and protreptics) with the master-disciple relationship that Professor Józef Lipiec declared to have with me, I would like to kindly remark - without questioning his possible and objectified mastery competences (among others as a 
teacher, educator, or supervisor) - that he has not inspired me philosophically at all and that he has never encouraged me in any philosophical studies: neither for taking up the philosophy of religion (including Christian philosophical anthropology), nor in studies on general methodology or longstanding inquiries concerning Greek philosophy. He also did not stimulate me in the critical perception of the following, among others:

a) Coubertinian and the contemporary assumptions of Olympism (see: Kosiewicz 2017d, pp. 5-13);

b) the already outdated absolutist interpretations of the fair play principle;

c) the supposedly fundamental influence of normative ethics on competitive, organized, professional, spectacular, Olympic, top-level, elite, marketable sport (Kosiewicz 2016c).

\section{Repetition - that is, coming back to youth}

Concerning the abovementioned dead, I do not pay unnecessary attention to my jubilees. I do not demand the connected honorable celebrations and distinctions. I do not seek to publish any commemorative books. I write my own ones - smaller and not very commemorative. The newest one, dedicated to Greek philosophy and entitled Od mitu petnego dziwów do włosów na czarnych dziurach - filozoficznie (From Myth Full of Wonders to Hair on Black Holes - Philosophically), has about 450 pages.

Recently, a surprising twist took place. Possible jubilees and commemorative books were postponed for the indefinite future. Many of my years were taken away - I was classified as a student.

If this was claimed by my primary or secondary school teachers, I would willingly admit to that affinity - even to academic teachers who also gave me D's, C's, B's, and - not so often - A's.

\section{Parlando - Glorification or objectivism?}

I have been blessed by Professor Józef Lipiec with a surprising distinction that was revealed, solemnly, during a recent conference. There, he called me his disciple. This was surprising because Józef and I (we are on a first-name basis) do not have any points in common in the fields of general philosophy and philosophical reflection on sport.

Nowadays, Prof. Józef Lipiec is appreciated first of all as an ideologist and promoter of contemporary Olympic sport, the founder of the Polish Olympic Academy affiliated with the Polish Olympic Committee. This is confirmed by two honorary doctoral degrees from the Universities of Physical Education in Cracow (2014) and Warsaw (2017). His strictly philosophical works have not been honored in such a way.

I would like to stress that I do not deal with apotheosis, sacralization, spiritualization, or any other axiological enhancement of the Olympic Games. I sometimes simply write about them, explain them, and try to understand how they were and how they are. I am of the opinion that at least two contradictory forms of statements are permitted in this case - much like in the German philosophy of the turn of the $18^{\text {th }}$ and $19^{\text {th }}$ centuries. They are permitted provided that their essence is properly justified. This refers to two philosophical geniuses: Hans Wilhelm Friedrich Hegel and Friedrich Nietzsche.

The first of them - a theologian by his education - attempted to prove in his philosophy of the state that the peak exteriorization of that institution - that is, one of the forms of social consciousness of the self-realizing absolute (constituting a form of a divine idea existing on earth) - is the German period and the connected institution of the German state.

On the other hand, the second of them - a classical philologist, the young head of the Chair of Classical Philology at the University of Basel (he achieved this position without a doctoral degree) - had a critical attitude towards Germany because he was of the opinion that the German culture, tradition, educational ideas, politics, and bourgeois morality or religion of the time needed radical reassessment.

The above contradistinction is to demonstrate that social - and simultaneously cultural - phenomena in science and philosophy should be characterized objectively. They should not be distorted by being attributed solely with positive and exaggerated qualities. They should be described, analyzed, interpreted, and explained impartially, which was done by Nietzsche, an unquestionable German patriot and an atheist coming from a traditional and numerous family deeply rooted in Protestant religion and theology. 
It comes from the abovementioned views of dialectical character that, among others, the Olympic Games - like German culture - should not be presented in a one-sided manner, e.g., only in a good light and avoiding or diminishing the importance and significance of their negative values, because they are human creations and a human being is by his nature inclined to sin, stigmatized with the Biblical sin. God -according to the Catholic interpretation - blesses him with deep caring love, loves him such as he is. He seeks a human being's salvation and eschatological happiness. In order to refine or improve the Olympic Games, their deficiencies, ailments, or flaws should be cognized, defined, and interpreted. After all, it is well known that - for example, in medicine - the proper therapy is impossible without a good diagnosis.

\section{Involuntary disciple}

If Professor Józef Lipiec had wanted to include me among members of his school, he should have talked to me about it. He has not done so thus far. He has not yet informed me about this surprising - in both its content and form - distinction. Maybe he was embarrassed or assumed that this would not be necessary; anyway, it appears strange.

Professor Józef Lipiec used to be a full professor at Jagiellonian University. That university usually grants this kind of professorship many years after the professor degree (I am using the present terminology) among other things, after proving that one has founded their own research school; for example, in the field of philosophy: a national, foreign, or mixed one. The professor fulfilled the national requirements.

Since I was not on his list of students at that time, he could talk to me and consult me about a newer version - especially regarding my possible involuntary presence on it. I would like to emphasize that although I appreciate and respect Professor Józef Lipiec, I did not seek that distinction and did not take into account such a possibility at all because I have not attended any philosophical courses in the philosophical school of Professor Józef Lipiec, nor have I participated in any cycle of his lectures or seminars.

I met Professor Józef Lipiec for the first time during my doctoral thesis defense in Warsaw in 1984. He always recalls it during meetings with a smaller or larger number of persons - even if there is no reason to do it, as if he is suffering from some obsession.

However - in several dozens of such cases - he has never referred to other more important facts from my biography: for example, to a habilitation in the field of the humanities, concerning philosophy, to the professor degree or to the degree honoris causa from Semmelweiss University in Budapest on the occasion of the $240^{\text {th }}$ anniversary of the foundation of that medical university (established in 1769), or to membership in the Advisory Committee of the American Academy of Sport. Professor Józef Lipiec knows very well about those and other significant international scientific and editorial relations as well as about organizational facts - he has been informed about them. When talking about my achievements to a smaller or a larger audience (I've heard this myself), he has always finished on the doctoral thesis written several decades ago, the thesis that he reviewed (and this was the key message of that information). I always listened to this curiously, without avoiding reflection on the peculiarity of that unique case (hence the "case study" in the title).

On that occasion, it is worth pointing out that I have participated as a reviewer in over forty doctoral, habilitation, and professor procedures in Poland and abroad, and it is difficult for me to remember all of the persons connected with them. In 1993, I co-reactivated in some sense the Doctoral Studies at the University of Physical Education in Warsaw, and I was their first director for two terms. Then - in the years 1993-1999 - it achieved the highest index of efficiency (that is, the relation between the number of defended doctoral theses and the number of students of those studies). I have never reminded persons connected with doctoral, habilitation, or professor procedures that I took part in them. I was pleased when they did it.

\section{Speaker and expert}

Later I met Professor Józef Lipiec at various national conferences and defenses of doctoral theses. I have always listened to him - like all others - with interest, because he is a good speaker and an expert in the discussed issues. This does not refer, however, to his interpretations of Olympism, which are too one-sided. In this case, he mainly acts as an ideologist and promoter who willingly - but redundantly - refers to the authority 
of philosophy. He confuses their qualities in spite of the fact that as a philosopher he knows very well that philosophy cannot be reconciled with ideology and promotion without being a detriment to it.

On the abovementioned occasions, he created something like a one-man show. He could - like no one else - attract attention. This also refers to social situations. Some kind of Witkacy-like theatralisation of accidental - that is, rare in his case - sociable lifestyle took place there. It was always based on sublime aleatoric associations saturated with a tactful and fine sense of humor. You would like to listen to him and laugh endlessly.

A similar sense of humor - although less sublime - used to characterize Bogusław Mec. During numerous - almost daily - escapades and feasts in restaurants and clubs, he flooded everyone with cascades of funny associations. New jokes kept pouring out of him (only God knows where he took them from and how he remembered them). He also aroused admiration - especially in those situations and during his concerts, being quite a good singer and an excellent self-announcer - by his unique ability of theatralisation of the abovementioned meetings. On the other hand, his marital life and familial community were as saturated with lasting parochial values as a clenched fist with a rosary inside.

\section{Scientific view and moralizing}

Professor Józef Lipiec probably has noble intentions when - in Homo Olimpicus (2017) and elsewhere - he tells athletes how they should behave and instructs them as to what is most important in their profession. He is convinced (and this emanates from his arguments) that his indoctrinatory endeavors are sensible although they are based on idealized and, I suppose, controversial values that are incompatible with everyday sports realities. This is proven by the moral demands in the axiological context of the idea of homo olimpicus, which he promotes (I also write about this in a text concerning doping in sport published in the presented book).

It can be inferred from arguments included in the book Homo Olimpicus that Professor Józef Lipiec has never been an athlete connected with competitive, organized, professional, spectacular, Olympic, top-level, elite, marketable sport. Instructing high-class and top-class professionals dealing with sport as to how they should practice and treat their profession is something like advising headhunters how to choose - in their isolated civilization - persons who are the most suitable for decapitation.

Scientific activity - in the field of philosophy, sociology, psychology, history, political science, or law - concerning, e.g., cultural values accompanying sports phenomena is one thing and suggesting - from the viewpoint of relative, optional, continuously changeable, and multiform normative ethics - how athletes and the connected social milieu should act and treat their profession is another (cf. Kosiewicz 2016c). It is worth knowing that they are usually prepared for it by specialists (e.g., trainers, coaches) or persons who have achieved national and international master class in particular sports for many years. Of course, a philosopher can proclaim his opinions on nature and even describe the anatomy and life of birds, as was done by Aristotle when he wrote that "Birds with curved claws fly well; birds with spurs fly heavily" (Zoology, Book II, chapter XII, 504b). But this is instructing them during their first steps, first attempts to fly, and feeding falls in their natural environment - I emphasize: in their natural environment - within the competence of their families and not of philosophers.

\section{Olympism - foundations of ethos}

Athletes who take part in the Olympic Games (the overwhelming majority of sportspersons do not take part in them and never will) stay in so-called villages, in arenas and outside of them from 2 to 4 weeks every 4 years. They spend the rest of their time providing for themselves and their families. They take part in league competitions, cup competitions, tournaments, and local, national, and international championships.

Unfortunately, it is not said that the most prestigious and profitable sports event in the world, which beats records for TV viewership and attracts the richest sponsors and advertisers, seeks - as a private company registered in the Swiss National Court Register - first and foremost its own exorbitant multi-billion profits. It does not provide financial support for the organizers of those usually more or less loss-making games. On the contrary, it demands high financial tributes from all game-related profits, which deepens their sometimes troublesome financial problems (this refers, for example, to the 2016 Olympic Games in Rio de Janeiro). 
Greediness is so overwhelming that the International Olympic Committee continues to refuse paying fees, financial prizes, and other financial remunerations to:

a) Athletes and coaches for their achievements in the Games, treating their highly demanding (regarding financial and personal expenses - physical, mental, and relational efforts), exhausting, and timeconsuming four-year preparatory non-Olympic hard work as worthless, "forgetting" that it is no longer a joyful ludic activity of sport-loving gentlemen from the turn of the $19^{\text {th }}$ and the $20^{\text {th }}$ centuries with their own independent sources of income (Kosiewicz 2017d, pp. 5-13);

b) Local organizers for their costly, multi-year sacrifices. It wants only volunteers.

It is worth pointing out for comparison that nowadays in great tennis tournaments, all athletes receive remunerations differentiated according to how they place: the weakest at least are returned the costs of participation and flights, and the winners of the Grand Slam tournament on the grass courts of Wimbledon get about one million six hundred thousand British pounds. Currently, these remunerations constitute about $8 \%$ of the total profit of those great tennis competitions.

Those who are encumbered with the costs of the Games by the International Olympic Committee are first of all local organizers and national Olympic committees. The IOC permits and cultivates draconian exploitation of all athletes - exploitation indubitably referring to the age of ravenous hunger of surplus value described by Karl Marx in Economic and Philosophic Manuscripts of 1844 (1962, pp. 548-634).

The statements of Professor Józef Lipiec about sport and Olympism are saturated with enthusiastic and noble moralism. They include demands of necessary and universal (according to his opinion) cultivation of unrealistic (according to my opinion) moral ideals. Admittedly, they are noble in reference to their ethical intentions and moral demands emphasizing homo olimpicus' inordinate selflessness both during four-year Olympiads and during the Olympic Games. (S)he is an ideal type, a kind of hypostasis, which, unfortunately, has little to do with the realities of contemporary (and not only contemporary) competitive, organized, professional, spectacular, Olympic, top-level, elite, or marketable sport (Kosiewicz 2017d, pp. 5-13). This refers somehow to his best work on sport and Olympism, Filozofia olimpismu (Philosophy of Olympism 1999).

\section{Disciple: Non-disciple}

Professor Józef Lipiec, like many other distinguished philosophers (and not only those who are distinguished, and not only those who are philosophers) has his characteristic - specific only to him - oddities.

He met me on the occasion of my doctoral thesis. After my doctoral defense it was, however, too late to make me his disciple - all the more so since I was already under the tutelage and competent organizational influence of Prof. Habilitated Dr. Zbigniew Krawczyk. He was supporting my studies, helping me get money for conducting them and for participation in conferences abroad and scholarships. He offered encouragement for writing papers and publishing books (and he sometimes jocularly complained that I wrote too many of them). For example, as the head of the Unit of Philosophy and Sociology and the rector of the University of Physical Education in Warsaw, he authorized my habilitation research concerning the conception of the human body in Christianity. I had devoted many years of work to them before the results appeared. So neither in the abovementioned case, nor directly after 1984 was there any subject-related cooperation or master-disciple relationship on philosophical ground between Professor Józef Lipiec and me.

My doctoral thesis was entitled "Physical Culture, Personality and Education. Methodological Issues" and was published in 1986. It was positively evaluated by Professor Józef Lipiec, but in the review that was read by him there was a remark that surprised me. It was difficult to say whether it was an objection or whether it was a compliment - probably it was a manifestation of flippancy, which is characteristic for him. This no longer surprises me, but it makes me wonder - that Gombrowiczian immaturity stuck in him like a thorn, an unbridled necessity of continuously improving one's own self-image in comparison to others. What amazes me is the reason of that phenomenon, in spite of the fact that I already know for certain that the world as such is full of unexplained wonders; that, for example, the myths and considerations of the universe - and especially metaphysics included in Aristotle's Metaphysics (1983) as well as the soft hair on the horizons of black holes described in "Soft Hair on Black Holes" by Stephen W. Hawking, Andrew Strominger, and Malcolm J. Perry (2016, pp. 1-9) - are also full of unexplained wonders. In the reasoning presented in the last sentence, I refer 
also to two chapters entitled "Introduction. Because Myth is Full of Wonders, As Soft Hair on Black Holes" (Kosiewicz 2017f, pp. 5-17) and "Aristotle and Everyday Thinking. Coming to Be, Passing Away and Hawking's Hair" (Kosiewicz 2017c, pp. 320-357) included in my book From Myth Full of Wonders to Hair on Black Holes - Philosophically (Kosiewicz 2017b).

Professor Józef Lipiec noticed that in chapters of my doctoral thesis concerning, for example, axiology, theory of culture, methodology of practical sciences, psychology, or pedagogy, I use a different language in each of them. I had the impression that in his opinion they should have been coherent, corresponding to each other regarding their style, expressions, and notions - like chapters in Wiesław Myśliwski’s prose (e.g., "Ostatnie rozdanie" ["The Last Hand"] 2013).

In my case, this was not possible. Neither was it possible in the works of philosophers such as Umberto Eco, Tadeusz Kotarbiński, or Władysław Tatarkiewicz, among others.

When Umberto Eco wrote Semiotic Landscape (1972), a criminal novel entitled The Name of the Rose (1987), a versified collection of short forms entitled Frivolous Philosophy (2008) - or when he was editing History of Beauty (2005) and History of Ugliness (2007) - he used a different language in each case (in spite of the fact that he was writing in Italian).

A similar situation takes place in the case of Tadeusz Kotarbiński, who - despite using Polish - wrote Traktat o dobrej robocie (A Treatise on Good Work 1982), which initiated the existence of praxeology, differently than an ethical treatise entitled Medytacje o życiu godziwym (Meditations on Diginified Life 1972) or the book of poems Rytmy i rymy (Rhythms and Rhymes 1970).

And Władysław Tatarkiewicz wrote the three-volume Historia filozofii (History of Philosophy 1970), which is saturated with challenging notions and essential descriptions and commentaries concerning great philosophers and is more suitable for philosophy graduates than for students of non-philosophical fields. Reading his Droga do filozofii (Road to Philosophy 1970) or Droga przez estetykę (Road Through Aesthetics 1972) - which seem to be intended for secondary school first-graders - is quite a different experience.

On that occasion, it is worth pointing out that each of the abovementioned parts of philosophy and each scientific discipline I referred to in particular chapters of my doctoral thesis uses a different method for communicating their message and applies a different specialized methodology in spite of the fact that similar principles of formal logic and general methodology concern all of them. There are differences concerning, first of all, the content of the abovementioned parts and disciplines. The fact that they use different languages is determined by what they deal with. Hence, they use terms, notions, interpretations, definitions, aspects, issues, assumptions, etc. that are characteristic only for them and that have been explained and interpreted in various contexts. For example, it would be difficult to persuade a general methodologist or a methodologist dealing with practical sciences to use - while considering significant substantive and simultaneously formal research issues from the field of their inquiries -ascertainments coming first of all from axiology, pedagogy, or psychology, and not from the field of their methodological specializations. Neither is there any common metalanguage that would enable competent description and explanation of the content of different scientific disciplines. A natural, everyday, conventional, and common-sense language is not suitable for that aim for obvious reasons (cf. Hołówka 1985; Czerwiński 1985, pp. 5-11; Kosiewicz 2015a, pp. 75-87; Kosiewicz 2016a, pp. 79-87; Kosiewicz 2016b, pp. 12-17; Kosiewicz 2017c, pp. 320-341). They are not applied and, consciously and openly, they are not treated as a basis for the exposition of assumptions of general methodology and principles included in definite specialized methodologies.

\section{Descriptive ethics or meta-ethics}

During one of last year's conferences, Professor Józef Lipiec, in private and in public, pointed out that my book Moralność $i$ sport (Morality and Sport) (Warszawa 2016c) is a manifestation of descriptive ethics. This surprised me because the book has, first of all, a meta-ethical character both in the substantive and the formal sense. It also creates - briefly speaking - new notions, conceptions, conceptualizations, and different interpretations of already classic canons of moral philosophy. In addition, it points out that normative ethics has an everyday, conventional, and common-sense character that is independent from truth and falsity in the logical sense (because it is evaluative and emotive). Hence, it is pluralistic, relativistic, voluntary, and 
panthareistic - it is continuously changeable because it undergoes gradual, evolutionary, radical, and even revolutionary transformations. Moreover, it can have (unrealizable):

- global aspirations for including all people;

- universal qualities: against the existing mainstream and superficial interpretations of Plato's (Kosiewicz 2016b, pp. 66-67) or Kant's (cf. Kosiewicz 2014d, pp. 12-13) philosophical conceptions, where - as a matter of fact - we have to deal with crypto-pluralism and ethical crypto-relativism.

My pronouncements from the fields of the ethics of sport and morality and sport concerning relations taking place between normative ethics and sport have not had a postulative character. They avoid instructing and giving moral guidance as a rule. Neither are they a form of ethics describing individual and social phenomena and moral behaviors in sport. They do not constitute - against the suggestions of Professor Józef Lipiec - a peculiar form of descriptive ethics of sport. This is possible only when it is assumed that all statements concerning morality describe (help to explain and understand) the sources, sense, and manifestations - mechanisms and applications - of moral values. In other words, this is only possible when it is assumed that also nomotetic and hermeneutic activity concerning morality always has a descriptive character - similar to connected descriptive endeavours because, after all, it characterizes, presents, discusses, or interprets its qualities. However, a philosopher, and especially a philosopher dealing with morality, should never use such a simplification since in the philosophy of morality - briefly speaking - there are distinguished normative ethics, descriptive ethics, and meta-ethics.

I would also like to emphasize that in the book Moralność $i$ sport (Morality and Sport) (Kosiewicz 2016c), the substantive stress (as it results from its content and is also suggested by the title) is put on morality - that is, on defining qualities of normative ethics mainly in relation to competitive, organized, professional, spectacular, Olympic, top-level, elite, marketable sport. Nowadays, they are the most popular - the most often watched and experienced via the mass media and in person - spectatorial form of phenomena in the field of mass culture. They especially influence superficial (that is, non-deepened) forms of mental experiences, described as the superficial spirituality of an emotional, cognitive, and volitional character (Kosiewicz 2015b, pp. 43-62; Kosiewicz 2016d, pp. 192-224).

In the monograph Moralność i sport (Morality and Sport) (Kosiewicz 2016c, pp. 88-89), as well as in the text "Sport poza dobrem i złem - uwagi i sugestie" ("Sport Beyond Good and Evil - Remarks and Suggestions") (Kosiewicz 2017e, pp. 11-13) included in the multi-author volume Spoleczne $i$ kulturowe aspekty sportu i turystyki (Social and Cultural Aspects of Sport and Tourism 2017d), I strongly emphasized that reflections in the texts concerning the ethics of sport do not have a normative character. It is not their aim to create "moral values and postulations (...). Neither are there dedicated to ideography - that is, to description of moral behavior taking place in sport" (Kosiewicz 2017e, pp. 1213). What they especially stress is that social phenomena - even those that, like sport, have mass character - should not necessarily and universally be saturated with assumptions from the field of normative ethics. For example, it turns out that morality - that is, moral norms - is external in its relation to what we call the sense, essence, and identity of sport and mechanisms and ways it manifests itself. Its foundations are constituted mainly by pragmatic (benefit and utility) and praxeological (successful influence) premises - not by strictly autotelic values, which are independent from them. Morality, religiousness, patriotism, ideas, and motivations of a tribal, familial, or similar character are of secondary significance in competitive, organized, professional, spectacular, Olympic, top-level, elite, marketable sport. The argumentations - that is, contexts of justification - included in the abovementioned monograph have a mainly metaethical character. The application of contexts of justification is oriented towards the neutralization of petrified and widespread opinions anchored in everyday, conventional, and common-sense thinking (independent from formal logic, philosophy, canons of scientific disciplines, and the connected specialized methodologies), pointing out that supreme values of sport are moral assumptions and an athlete is first of all a noble missioner whose main vocation is to set a proper example, to promote and popularize ethical good. 


\section{Academic degree and nuances}

Some of the abovementioned fragments of statements point to the differences existing between me and Professor Józef Lipiec, which - in my opinion - could not provide a basis for proclaiming the existence of a master-disciple relationship. Before I move to a fuller justification of its absence, I will emphasize something extraordinary that causes Professor Józef Lipiec to deserve my special respect.

This refers to the procedure connected with getting my professor degree. He promised to support solicitations in the Cracow University of Physical Education. He made a lot of selfless effort in order to get the procedure started. He also became a reviewer of a motion for conferring the professor degree, along with Prof. Habiliteted Dr. Tadeusz Maszczak and Prof. Habilitated Dr. Andrzej Pawłucki. In spite of positive evaluations and academic achievement exceeding the standards of the time, all the reviewers had to fight a fierce battle with a procedural commission that had been set up in one of the faculties of that excellent university and whose initial attitude was reluctant. The whole procedure ended positively in 2003. It was achieved mainly thanks to the stance of the abovementioned professors. Each of them, the dean, and the faculty council (for objectivity) deserve obeisance.

It is worth adding that the substantive and formal evaluation of the abovementioned commission was attached by me - besides multi-author volumes and many other texts - with my six monographs:

Kosiewicz, J. (1986). Kultura fizyczna, osobowość wychowanie. Zagadnienia metodologiczne [Physical Culture, Personality, Education. Methodological Issues]. Warszawa: Wydawnictwo AWF.

Kosiewicz, J. (1992). Czeławiek i jego tieło w doktrynie Cerkwi I ketoliczeskoj fiłosofii. Moscow: INION Russian Academy of Sciences, Diepon. No. 462258.

Kosiewicz, J. (1997). Bóg, cielesność i przemoc [God, Corporeality, and Violence]. Warszawa: Wydawnictwo Aletheia.

Kosiewicz, J. (1998a). Myśl wczesnochrześcijańska i katolicka wobec ciała [Attitude of Early Christian and Catholic Thought Towards the Body]. Warszawa: Wydawnictwo "Witmark."

Kosiewicz, J. (1998b). Bóg, cielesność i miłość [God, Corporeality, and Love]. Warszawa: Wydawnictwo Aletheia.

Kosiewicz, J. (2000). Kultura fizyczna i sport w perspektywie filozofii [Physical Culture and Sport from a Philosophical Perspective]. Warszawa: Wydawnictwo AWF.

All the aforementioned books have a philosophical character. Four of them concern the philosophy of religion, especially Christian anthropology rooted in Judaism, as well as in Hellenic beliefs and Greek philosophy. The other two include philosophical reflections on physical culture, sport, personality, and education.

\section{On factual and substantive differences}

For a long time, Professor Józef Lipiec referred to Marxism. After the Second World War, Marxism continued to be popular in the West - in Italy, France, and Germany, among other places - in various milieus of educated persons, for example among artists and philosophers. This refers to J.-P. Sartre (a philosopher dealing with existentialism, a distinguished prose writer and playwright, and a member of the communist party), Emmanuel Mounier (a personalist philosopher referring to Marxian humanism), Albert Camus (a philosopher dealing with existentialism, a prose writer and a playwright, and a member of the communist party), Pablo Picasso (a painter and a member of the communist party), and Yves Montand (once an extremely popular French actor and singer of Italian origin and a member of the communist party).

In Poland, before the political breakthrough of 1981, interest in Marxist philosophy was either authentic or imposed (sometimes opportunistic). Dealing with Marxian or Marxist subjects often resulted from real research needs, like in the case of Mark Fritzhand (a party member at the University of Warsaw), who wrote the monograph Myśl etyczna młodego Marksa (Young Marx's Ethical Thought 1976), or Józef Lipiec, who was a party member at the Jagiellonian University. Before the aforementioned breakthrough among members of the Polish United Workers' Party, there were also distinguished Polish philosophers such as Ryszard Panasiuk, Wacłam Mejbaum, and Marek Siemek. 
On the other hand, I - having graduated philosophy - was interested in methodology, the philosophy of religion, philosophical anthropology, and conceptions of the body (and their sources) in various Christian orientations and currents as well as in theatrology. I was not an enthusiast of communism and socialism and in spite of pressures and "unnegotiable propositions" - I did not join the PUWP and did not accept an attractive (in its financial and research conditions) proposal of employment under the supervision of Prof. Habilitated Dr. Henryk Swienko at the Institute of Religious Studies of the University of Social Sciences in Warsaw in 1989 (nota bene the school was closed down half a year later). It probably would have been a substantively fruitful cooperation, as during the next several years I prepared my habilitation dissertation and published the four aforementioned books as well as about a dozen extensive papers in good journals from the field of philosophy, religious studies, and other humanities in Poland and abroad. These included Kwartalnik Filozoficzny, Edukacja Filozoficzna, Przeglad Filozoficzny, Przeglad Humanistyczny, Euhemer. Przeglad Religioznawczy, Roczniki Naukowe AWF w Warszawie, and Filosofskiye Nauki (then the best philosophical journal in Russia). Its editor-in-chief, A.T. Pawlow, who was also one of the three main reviewers in my habilitation procedure, published two excerpts from my dissertation as autonomous texts. They pertained to the human body, sex, and erotic love in Christian thought intermediated not only in the text of the Old and New Testaments, but also - significantly - in religious and philosophical anthropology of Greek antiquity.

A significant part of my interests - regarding my adolescent fascinations and my employment at the University of Physical Education in Warsaw, which I was offered after several-year-long attempts (I worked in the Department of Philosophy of the Medical Academy in Lódź for 6 years) - was constituted by philosophical reflection on sport. In spite of this, I have never maintained that I am a philosopher of sport because I am of the opinion that - for formal reasons - such a discipline does not yet exist. I justified this viewpoint during several foreign and national conferences (for example, at a conference of the International Association for the Philosophy of Sport in Olomouc in 2005). I publicized this in shorter and longer versions in a less or more mature form in Poland and abroad - mainly in English (Kosiewicz 2008/2009, pp. 5-38; Kosiewicz 2010, pp. 46-86).

I wrote in these texts that the so-called philosophy of sport cannot be recognized and treated as an autonomous and mature philosophical discipline because it does not yet have a specialized methodology characteristic solely for this discipline. Hence, it refers to assumptions of general methodology and of specialized methodologies of various branches and parts of philosophy and various philosophical disciplines and specializations - such as, e.g., social philosophy, the philosophy of law, the philosophy of religion (when referring to the ancient Olympic Games), the philosophy of man, and the philosophy of biology.

This is why it is worth pointing out that an indispensable (necessary in the Kantian sense) precondition for the autonomy and maturity of each scientific discipline is its specific specialized methodology. It can draw from external sources or inspire other disciplines, but - regardless of the kind and scope of borrowing and externalizations - it should necessarily have a so-called methodological core that is strictly, formally, and substantively connected with a given kind of philosophy.

The factors that already exist and that matter in that pursuit of the aforementioned relative autonomy are of course publishing and organizational and functional determinants, such as:

- a high number of publications: books, chapters in multi-author volumes, papers in scientific journals and specialist periodicals in the field of the so-called philosophy of sport;

- scientific organizations, such as the International Association for the Philosophy of Sport, the European Association for the Philosophy of Sport, the British Philosophy of Sport Association, and other national associations, such as those existing in the Czech Republic, Japan, or the USA;

- departments, chairs, and institutes scattered all around the world dealing with teaching and research in the aforementioned field and having the term "philosophy of sport" in their names.

The only thing missing is a specialized methodology, and this precludes the coming into being of that discipline. It is difficult to foresee when it will finally occur. That is why - in my opinion, as a philosopher and a methodologist by my education - we have to deal with philosophical reflection on sport and not with a philosophy of sport. Everyday, conventional criteria are not enough. The aforementioned formal condition must be met because it is impossible to be partially pregnant - it is an either-or situation. 
In conclusion, I would like to emphasize - taking into account the above argument and the included justification - that I cannot and am not going to describe myself as a philosopher of sport. As a philosopher by profession, I deal, among things, with philosophical reflection on sport. Its results are noticeable in Poland and abroad. This refers also to philosophical anthropology, the philosophy of religion, Greek philosophy, and general methodology.

None of my texts connected with philosophical reflection on sport correspond in their content with the works of Professor Józef Lipiec, and especially with his written and oral statements concerning the characteristics of substantive and formal assumptions of Olympism. This can be noticed in my chapter of the presented multi-author volume dedicated to doping in sport ("Pochwała dopingu w sporcie - o jego konieczności i użyteczności" ["In Praise of Doping in Sport - On Its Necessity and Usefulness]), both in its main parts and its footnotes.

I am of the opinion that the Olympic Games, which take place once every four years (both the summer and the winter Games), do not contribute at all - contrary to what is maintained by ideologists and promoters of Olympism - to the development of particular sports. The development and improvement of athletes' qualities are laboriously worked on by sportspersons and coaches, as well as by people from their milieus. This enables athletes to take part in various competitions on various levels and to earn money and provide for themselves during the many years of their sports careers.

The overwhelming majority of those disciplines are niche sports, not very attractive regarding their spectacularity. Interest in them dies down during the four-year break between the Games. These may include, for example, shot put, hammer throw, canoeing, rowing, sailing, various forms of wrestling and gymnastics, swimming, diving, fencing, or almost all the sports of the Winter Games except cross-country and downhill skiing and ski jumping, because there is competition between the representatives of countries where those sports have many enthusiastic fans.

The Winter Games are not thought to be interesting in states from Africa, Mesoamerica and South America, Australia and Oceania, Mexico, India, Pakistan, or Bangladesh. Neither was the organization of the Winter Games demanded by ancient or contemporary Greece or Baron de Coubertin. They came into being as a result of pressures from states from the northern part of the northern hemisphere of our planet - that is, states whose existence was not known to Panhellenic culture and civilization.

What makes Professor Józef Lipiec and me considerably different is the scope of library research, its application in the main text, and bibliographic records. I do not follow his example. $\mathrm{He}$ - in contrast to me hardly refers (even nowadays) to literature published in English. English literature is rarely and vestigially used in his texts. It is rudimentarily mentioned in footnotes and bibliographies (cf. Lipiec 2005a; Lipiec 2005b).

Nowadays, literature in English is the most representative in the world of science. It is not only literature from English-speaking countries, but also texts created by authors from non-English-speaking countries, as there is a considerable number of valuable journals published in English that usually enjoy specialists' significant esteem. This also refers to considerations from the field of sport social sciences. At the turn of the $20^{\text {th }}$ and $21^{\text {st }}$ centuries, many books and papers concerning so-called Olympism were published. Professor Józef Lipiec does not pay much attention to them (cf.: Lipiec 2007; Lipiec 2017).

Besides his research intuitions objectified in the texts, a bibliography published by him constitutes some general basis or source of inspirations, but there is often no precise information concerning what (which fragment) and who have creatively inspired Professor Józef Lipiec for affirmation and development of an idea or polemic. I do not judge this to be good or bad. Neither do I refer to the techniques used by Professor Józef Lipiec in practicing philosophy in the aforementioned cases. However, it is obvious for me that if I applied such bibliographical principles to my own work, none of the significant national or foreign scientific periodicals - including Physical Culture and Sport. Studies and Research (PCSSR), where I am the Editor-inChief - would publish my texts.

I emphasize that in my case English-language literature has been significantly and clearly represented in texts (in the main body, footnotes, and references) for many years; the bibliography only includes information about the texts I refer to in my pronouncements. I have even made a modest contribution to English-language scientific literature. I published two of my books in English (Sport and Philosophy. From 
Methodology to Ethics, Kosiewicz 2010; Sport and Ethics. Philosophical Studies, Kosiewicz 2014). Besides this, I have published 22 multi-author volumes (which I have edited or co-edited), about 200 papers, and 32 issues of the English-language journal Physical Culture and Sport. Studies and Research.

Moreover, I was a member of the Founding Committee and then - in the years 2002-2010 - of the Editorial Board of the European Journal for Sport and Society (first published in Münster, Germany and then in Berne, Switzerland), which has had a significant impact factor for many years. I also founded - and was the first Editor-in-Chief of - PCSSR, the aforementioned journal published by the University of Physical Education in Warsaw, which has received a great deal of attention from readers in countries that speak English as a native language, as well as those that do not. I did not follow Professor Józef Lipiec in these cases.

A similar situation has occurred in the field of my activity in 10 foreign scientific associations dealing with, among other things, the philosophy of religion, Greek philosophy, and philosophical premises for universal dialogue. Hence I have been a member of the European Society for Study of Science and Theology (ESSSAT) since 1994, a member of the International Association of Greek Philosophy (IAGP) since 2007, and a member of the International Society for Universal Dialogue (ISUD) since 1989. The last of them is the association affiliated with the University of Warsaw (I was its founding member and the chairperson of the Organization Committee of the founding congress in 1989). From its beginning and for a long time afterwards, it was directed by Prof. Habilitated Dr. Janusz Kuczyński.

Moreover, in 2001 I was a co-founder - along with Prof. Dr. Otmar Weiss from the University of Vienna - of the European Association for Sociology of Sport. I acted as Vice President until 2008. That year, I also became a member of the Founding Committee of the European Association for the Philosophy of Sport. I was a member of that organization's board twice - that is, for two terms. In 2009, I founded the International Society for the Social Sciences of Sport and I currently act as the chairperson of that association.

In none of the aforementioned cases have I followed the example of Professor Józef Lipiec, as - if I remember correctly - he does not have experience with this kind of activity in the field of philosophy and philosophical reflection on sport.

This also refers to my cooperation (as a member of editorial teams) with 20 foreign scientific journals from Europe, North America, South America, Asia, and Africa - and, moreover, with a scientific publishing house from Rome as a member of the scientific committee.

I have been invited three times, as a juror and a member of scientific committees, for students' international scientific conferences taking place abroad.

Moreover, I have participated 84 times - with oral presentations - in scientific conferences taking place abroad in European and non-European countries.

I have also presented - independently from the aforementioned fact - 33 papers as the keynote speaker in Europe, Mesoamerica, South America, Asia Minor, and Africa.

Independently from the abovementioned facts, I have also:

a) acted abroad as a consultant 20 times - mainly in Western countries and because of my own and international scientific research, as well as in connection with organizational issues of the scientific association boards of which I was an elected member;

b) been a visiting professor 33 times, mainly in European countries.

In the abovementioned case, I did not follow the example of scientific activity of Professor Józef Lipiec, either.

Neither did mimetic needs underpin:

a) My activity connected with the honorary doctoral degree I received from Semmelweis University in Budapest in 2009. Professor Józef Lipiec received that type of degree from the University of Physical Education in Cracow several years later in 2014.

b) My patronage - as "the main Patron of the Conference," a title I received as the chairperson of the International Sports Social Sciences Association - of a scientific conference of the Visegrad group countries. The conference took place in Budapest in the Hungarian Academy of Sciences in 2011 (A. Galdine Gal, 2001, pp. 1, 32-33) thanks to the efforts of Prof. Dr. Gyongyi Foldesi from Semmelweis University. 
In summary - and on the basis of the aforementioned data - I kindly ask Professor Józef Lipiec not to call me his disciple. Obviously, I highly appreciate numerous publications, conference presentations, and other effects of the professor's scientific studies. I also admire his noble intentions underpinning his increased activity of a pro-sport and pro-Olympic character and I carefully follow its results.

Professor Habilitated Dr. Józef Lipiec was also so kind and generous that he honored the Polish Sports Social Sciences Associations (for whom I act as chairperson) with an acceptance of the proposal of Honorary Membership, and he considerably enriched two conferences of the association by presenting papers as the keynote speaker.

\section{REFERENCES}

Arystoteles (1983). Metafizyka [Metaphysics]. Warszawa: PWN.

Arystoteles (1982). Zoologia [Zoology]. Warszawa: PWN.

Czerwiński, M. (1986). Wstęp [Introduction]. In T. Hołówka, Myślenie potoczne [Everyday Thinking]. Warszawa: PWN. Diogenes Laertius (1972). Lives of Eminent Philosophers, http://www.perseus.tufts.edu/hopper/text?doc=Perseus\%3Atext\%3A1999.01.0258\%3Abook\%3D2\%3Achapter\%3D5.

Domański, J. (1996). Metamorfozy pojęcia filozofii [Metamorphoses of the Notion of Philosophy]. Warszawa: Polska Akademia Nauk, Instytut Filozofii i Socjologii.

Eco, U. (1987). Imię róży [The Name of the Rose]. Warszawa: PIW.

Eco, U. (1987). Pejzaż semiotyczny [Semiotic Landscape]. Warszawa: PIW.

Eco, U. (Ed.) (2005). Historia piękna [History of Beauty]. Poznań: Dom Wydawniczy REBOS.

Eco, U. (Ed.) (2007). Historia brzydoty [History of Ugliness]. Poznań: Dom Wydawniczy REBOS.

Eco, U. (2008). Filozofia frywolna [Frivolous Philosophy]. Kraków: Wydawnictwo M.

Fritzhand, M. (1978). Myśl etyczna młodego Marksa [Young Marx's Ethical Thought]. Warszawa: Wydawnictwo Książka i Wiedza.

Galdine Gal, A. (2011). Report of V4 Conference. Hungarian Review of Sport Science, pp. 1, 32-34.

Hawking, S.W., Perry, M.J., \& Strominger, A. (2016). Soft hair on black holes. Physical Review Letters, 116, 231301-1 $-231-301-9$.

Hołówka, T. (1986). Myślenie potoczne [Everyday Thinking]. Warszawa: PIW.

Kosiewicz, J. (1986). Kultura fizyczna, osobowość, wychowanie. Zagadnienia metodologiczne [Physical Culture, Personality, Education. Methodological Issues]. Warszawa: Wydawnictwo AWF.

Kosiewicz, J. (1992). Czeławiej i jego tieło w doktrynie Cerkwi i katoliczeskoj fiłosofii. Moscow: INION Russian Academy of Sciences. No 462258.

Kosiewicz, J. (1997). Bóg, cielesność i przemoc [God, Corporeality, and Violence]. Warszawa: ALETHEIA

Kosiewicz, J. (1998a). Myśl wczesnochrześcijańska i katolicka wobec ciała [Attitude of Early Christian and Catholic Thought Towards the Body]. Warszawa: Wydawnictwo "Witmark."

Kosiewicz, J. (1998b). Bóg, cielesność i milość [God, Corporeality, and Love]. Warszawa: Wydawnictwo Aletheia.

Kosiewicz, J. (2000). Kultura fizyczna i sport w perspektywie filozofii [Physical Culture and Sport from a Philosophical Perspective]. Warszawa: Wydawnictwo AWF w Warszawie.

Kosiewicz, J. (2008/2009). Philosophy of sport from the institutional, content related and methodological viewpoint. Physical Culture and Sport. Studies and Research, 46(1), 5-38.

Kosiewicz, J. (2010). Philosophy of sport from the institutional, content related and methodological viewpoint. In J. Kosiewicz (Ed.), Sport and Philosophy. From Methodology to Ethics (pp. 46-48). Warszawa: Wydawnictwo BK.

Kosiewicz, J. (2014a). Sport and ethics, philosophical studies. Physical Culture and Sport. Studies and Research, 62. 
Kosiewicz, J. (2014b). Normative ethics and sport: A moral manifesto. Physical Culture and Sport. Studies and Research, 62(1), 5-22. DOI: 10.2478/pcssr-2014-0008.

Kosiewicz, J. (2015a). Why pluralism, relativism, and panthareism: An ethical landscape with sport in the background. Physical Culture and Sport. Studies and Research, 66(1), 75-87. DOI: 10.1515/pcssr-2015-0015.

Kosiewicz, J. (2015b). Professional, spectator, and Olympic sport in the context of the terms spiritualism and spirituality, and in the context of normative ethics. Physical Culture and Sport. Studies and Research, 68(1), 43-62. DOI: 10.1515/pcssr-2015-0024.

Kosiewicz, J. (2016a). Considerations on relations between philosophy and sport and common sense thinking. Physical Culture and Sport. Studies and Research, 72(1), 79-87. DOI: 10.1515/pcssr-2016-0010.

Kosiewicz, J. (2016b). Pejzaż etyczny ze sportem w tle [Ethical landscape with sport in the background]. In J. Kosiewicz (Ed.), Moralność i sport [Morality and Sport] (pp. 5-49). Warszawa: Międzynarodowe Towarzystwo Nauk Społecznych o Sporcie.

Kosiewicz, J. (2016c). Moralność i sport [Morality and Sport]. Warszawa: Międzynarodowe Towarzystwo Nauk Społecznych o Sporcie.

Kosiewicz, J. (2016d). Sport widowiskowy, zawodowy i olimpijski $w$ kontekście pojęć spirituality $i$ spiritualism and normative ethics. Moralność i sport [Professional, Spectacular and Olympic Sport in the Context of Notions of Spirituality and Spiritualism. Morality and Sport]. Warszawa: Międzynarodowe Towarzystwo Nauk Społecznych o Sporcie, pp. $192-$ 224.

Kosiewicz, J. (2017a). Filozofia w tyglu etymologii i szaleństwa [Philosophy in the melting pot of etymology and madness]. In J. Kosiewicz (Ed.), Od mitu petnego dziwów do włosów na czarnych dziurach - filozoficznie [From Myth Full of Wonders to Hair on Black Holes - Philosophically] (pp. 94-144). Warszawa: Wydawnictwo AWF w Warszawie oraz MTNSS.

Kosiewicz, J. (2017c). Arystoteles i myślenie potoczne. Powstawanie i ginięcie a włosy Hawkinga [Aristotle and everyday thinking. Coming to be, passing away, and Hawking's hair]. In J. Kosiewicz (Ed.), Od mitu pełnego dziwów do włosów na czarnych dziurach - filozoficznie [From Myth Full of Wonders to Hair on Black Holes - Philosophically] (pp. 320357). Warszawa: Wydawnictwo AWF w Warszawie oraz MTNSS.

Kosiewicz, J. \& Bochenek, A. (Eds.) (2017d). Społeczne i kulturowe aspekty sportu i turystyki [Social and Cultural Aspects of Sport and Tourism]. Biała Podlaska: Wydawnictwo AWF w Warszawie, Wydział Wychowania Fizycznego i Sportu w Białej Podlaskiej.

Kosiewicz, J. (2017e). Sport poza dobrem i złem [Sport beyond good and evil]. In J. Kosiewicz \& A. Bochenek (Eds.), Społeczne i kulturowe aspekty sportu i turystyki [Social and Cultural Aspects of Sport and Tourism] (pp. 11-26). Biała Podlaska: Wydawnictwo Akademia Wychowania Fizycznego Józefa Piłsudskiego w Warszawie, Wydział Wychowania Fizycznego i Sportu w Białej Podlaskiej.

Kosiewicz, J. (2017f). Wprowadzenie. Bo mit jest pełen dziwów, jak miękkie włosy na czarnych dziurach [Introduction. Because myth is full of wonders, as soft hair on black holes]. In J. Kosiewicz (Ed.), Od mitu petnego dziwów do włosów na czarnych dziurach - filozoficznie [From Myth Full of Wonders to Hair on Black Holes - Philosophically] (pp. 320357). Warszawa: Wydawnictwo AWF w Warszawie oraz MTNSS.

Kotarbiński, T. (1970). Rytmy i rymy [Rhythms and Rhymes]. Warszawa: Czytelniki.

Kotarbiński, T. (1966). Medytacje o życiu godziwym [Meditations on Dignified Life]. Warszawa: Wiedza Powszechna.

Kotarbiński, T. (1982). Traktat o dobrej robocie [A Treatise on Good Work]. Warszawa: Ossolineum.

Lipiec, J. (1999). Filozofia olimpizmu [Philosophy of Olympism]. Poznań: AWF w Poznaniu.

Lipiec, J. (2005a). Powrót do estetyki [Return to Aesthetics]. Kraków: Wydawnictwo FALL.

Lipiec, J. (2005b). Koło etyczne [Ethical Circle]. Kraków: Wydawnictwo FALL.

Lipiec, J. (2007). Pożegnanie z Olimpia [Farewell to Olympia]. Kraków: Wydawnictwo FALL.

Lipiec, J. (2017). Homo Olimpicus. Kraków: Wydawnictwo FALL. 
Marks, K. (1962). Rękopisy ekonomiczno-filozoficzne z 1844 roku [Economic and philosophic manuscripts of 1844]. In K. Marks \& F. Engels (Eds.), Dzieła [Works], Vol. 3 (pp. 548-634). Warszawa: KiW.

Myśliwski, W. (2013). Ostatnie rozdanie [The Last Hand]. Kraków: Społeczny Instytut Wydawniczy Znak.

Pseudo-Platon (1973). Definicje [Definitions]. In Alkibiades $i$ inne dialogi oraz definicje [Alkibiades and Other Dialogues and Definitions] (pp. 150-191). Warszawa: PWN.

Tatarkiewicz, W. (1970). Historia filozofii [History of Philosophy], Vol. 1-3. Warszawa: PWN.

Tatarkiewicz, W. (1971). Droga do filozofii [Road to Philosophy]. Warszawa: PWN.

Tatarkiewicz, W. (1972). Droga przez estetykę [Road Through Aesthetics]. Warszawa: PWN.

AUTHOR'S ADDRESS: Jerzy Kosiewicz

Josef Pilsudski University of Physical Education in Warsaw

Department of Philosophy and Sociology

00-968 Warsaw

34 Marymoncka str.

Poland

E-mail: jerzy.kosiewicz@awf.edu.pl

Received: 2 April 2018; Accepted: 21 May 2018 